\title{
Comparative peptidomics of the endocrine pancreas: islet hormones from the clawed frog Xenopus laevis and the red-bellied newt Cynops pyrrhogaster
}

\author{
J M Conlon, J B Kim ${ }^{1}$, A Johansson ${ }^{2}$ and S Kikuyama ${ }^{3}$ \\ Department of Biochemistry, Faculty of Medicine and Health Sciences, United Arab Emirates University, PO Box 17666 Al-Ain, United Arab Emirates \\ ${ }^{1}$ Regulatory Peptide Center, Department of Biomedical Sciences, Creighton University Medical School, Omaha, Nebraska 68178-0405, USA \\ ${ }^{2}$ Department of Zoophysiology, University of Göteborg, SE 40530 Göteborg, Sweden \\ ${ }^{3}$ Department of Biology, School of Education, Waseda University, Nishi-Waseda 1-6-1, Shinjuku-ku, Tokyo 169-8050, Japan \\ (Requests for offprints should be addressed to J M Conlon; Email: jmconlon@uaeu.ac.ae)
}

\begin{abstract}
Electrospray mass spectrometry coupled with reversephase HPLC was used to identify peptides in the molecular mass range 3000-6000 Da in extracts of the pancreata of the clawed frog Xenopus laevis (Anura: Pipidae) and the red-bellied newt Cynops pyrrhogaster (Caudata: Salamandridae). Amino acid sequences of insulins, peptides derived from the post-translational processing of proglucagons and pancreatic polypeptide were determined by automated Edman degradation. Three molecular forms of insulin were isolated from the tetraploid organism $X$. laevis that represent insulin-1 and insulin-2, as deduced from the nucleotide sequences of previously characterized cDNAs, and a third form which differed from insulin-2 by the single amino acid substitution $\mathrm{Asp}^{21} \rightarrow \mathrm{Glu}$ in the B-chain. The amino acid sequence of Xenopus preproglucagons (genes 1 and 2 ) may be deduced from the nucleotide sequences of cDNAs but the pathways of post-translation processing of the precursors are not
\end{abstract}

known. Two molecular forms of glucagon with 36 amino acids, derived from genes 1 and 2 and representing glucagon-29 extended from its C terminus by different heptapeptides, and five molecular forms of glucagon-like peptide 1 (GLP-1) were isolated. The GLPs represent proglucagon-(77-113), -(122-158) and -(160-191) from gene 1, and proglucagon-(77-113) and -(160-191) from gene 2. A single molecular form of insulin, glucagon-36, a C-terminally $\alpha$-amidated GLP-1 with 30 amino acid residues, a 33 amino acid residue GLP-2 and pancreatic polypeptide were isolated from the pancreatic extract of the diploid organism C. pyrrhogaster. This study has illustrated the power of electrospray mass spectrometry for the rapid and reliable identification of peptides in chromatographic fractions without the need to use radioimmunoassay, radioreceptor assay or bioassay.

Journal of Endocrinology (2002) 175, 769-777

\section{Introduction}

The term 'proteomics' refers to the ambitious attempt to identify all the proteins/peptides, including posttranslational modifications, present in a particular tissue of a particular organism with a view to understanding changes in the pattern of expression in response to physiological and pathophysiological stimuli. Until very recently, the goal of proteomics was unrealistic but elucidation of the nucleotide sequence of the human genome, methodological advances in the automation of high throughput techniques of two-dimensional electrophoresis coupled with mass spectrometry (Dongre et al. 2001, Liu et al. 2002, Rabilloud 2002) and a strong commitment to proteomics research by the biotechnology industry mean that we are in the midst of an explosion of data relating to human proteomics.
The field of vertebrate comparative genomics/ proteomics is in its relative infancy. Attempts to characterize the genomes and/or proteomes of non-human species in a systematic fashion have been confined to those species that are commonly used in molecular research projects, such as the mouse (Klose et al. 2002), rat (Jacob \& Kwitek 2002), zebrafish Danio rerio (Patton \& Zon 2001), pufferfish Takifugu rubripes (Venkatesh et al. 2000) and medaka Oryzias latipes (Wittbrodt et al. 2002). These organisms are highly derived and the extent to which they are 'representative' of the class or order to which they belong is a matter for debate. With regard to the rest of the approximately 40000 species of vertebrates, sequence information, whether at the nucleotide or amino acid level, has been obtained sporadically as investigators have focused upon a particular gene, cDNA or gene product on the basis of its known biological function, e.g. enzyme, 


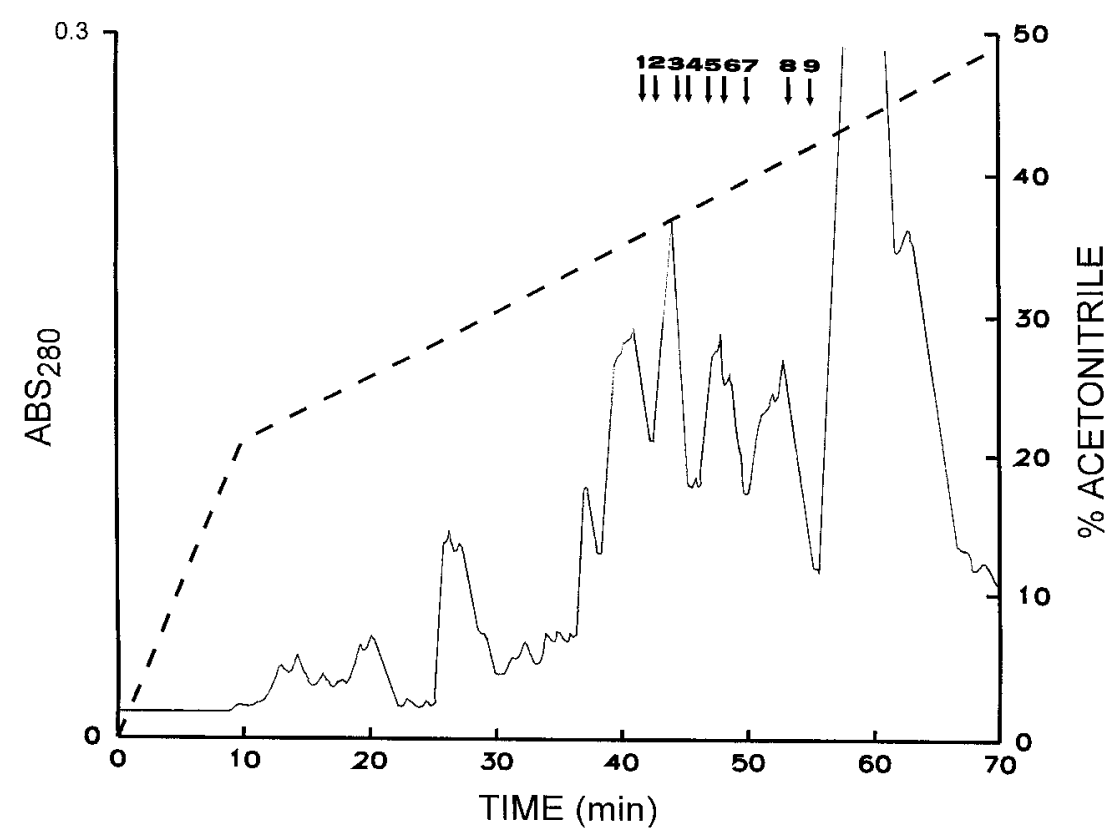

Figure 1 Reverse-phase HPLC on a Vydac C-18 column of an extract of the pancreas of Xenopus laevis after partial purification by gel permeation chromatography. The retention times of the islet hormones are denoted by: (1) glucagon-36 from genes 1 and 2, (2) insulin from gene 1, (3) insulin from gene 2, (4) insulin from gene 3, (5) GLP-1B from gene 1, (6) GLP-1C from gene 1, (7) GLP-1C from gene 2, (8) GLP-1A from genes 1 and 2 and (9) PP from genes 1 and 2. The broken line shows the concentration of acetonitrile in the eluting solvent. $\mathrm{ABS}_{280}$, absorbance at $280 \mathrm{~nm}$.

receptor, neurohormone, or have concentrated upon the mitochondrial genome for the purpose of phylogenetic analysis (Saccone et al. 2002).

The aim of the present study was to use electrospray mass spectrometry coupled with reverse-phase HPLC for the rapid identification and simultaneous purification of islet hormones (insulin, glucagon, glucagon-like peptide 1 (GLP-1), GLP-2 and pancreatic polypeptide (PP)) present in a pancreatic extract. The techniques are applied to the clawed frog Xenopus laevis (Anura: Pipidae), a tetraploid organism for which the nucleotide sequences of cDNAs encoding two preproinsulins (Shuldiner et al. 1989) and two preproglucagons (Irwin et al. 1997) are known, and to the Japanese red-bellied newt Cynops pyrrhogaster (Caudata: Salamandridae), a diploid organism whose islet preprohormones have not been characterized at the nucleotide sequence level.

\section{Materials and Methods}

\section{Tissue extraction}

All experiments involving X. laevis were approved by the University of Göteborg Animal Ethical Committee. All experiments involving C. pyrrhogaster were carried out in accordance with the Guide for the Care and Use of
Laboratory Animals prepared by Waseda University. Neither species is endangered. Pancreata $(6.8 \mathrm{~g})$ were removed from adult specimens of $X$. laevis of both sexes $(n=50)$ by dissection immediately after they had been killed as previously described (Kim et al. 2001). Pancreata $(1 \cdot 35 \mathrm{~g})$ were similarly removed from adult, male specimens of $C$. pyrrhogaster $(n=100)$. The samples were stored at $-80{ }^{\circ} \mathrm{C}$ until the time of extraction. Tissues were separately homogenized with ethanol/0.7 M HCl (3:1 $(\mathrm{v} / \mathrm{v}) ; 10 \mathrm{ml} / \mathrm{g})$ using a Waring blender and stirred for $2 \mathrm{~h}$ at $0{ }^{\circ} \mathrm{C}$. After centrifugation ( $4000 \boldsymbol{g}$ for $30 \mathrm{~min}$ ), ethanol was removed from the supernatants under reduced pressure. After a further centrifugation ( $4000 \boldsymbol{g}$ for $30 \mathrm{~min}$ ), each extract was pumped at a flow rate of $2 \mathrm{ml} / \mathrm{min}$ through six Sep-Pak C-18 cartridges (Waters Associates, Milford, MA, USA) connected in series. Bound material was eluted with acetonitrile/water/trifluoroacetic acid $(70 \cdot 0 / 29 \cdot 9 / 0 \cdot 1)$ and freeze-dried.

\section{Purification of the Xenopus peptides}

The pancreatic extract, after partial purification on SepPak cartridges, was subjected to gel permeation chromatography on a Sephadex G-25 column (Pharmacia, Uppsala, Sweden) under the conditions previously described (Kim et al. 2001). The fractions with $K_{\mathrm{AV}}$ 
Xenopus laevis

$\begin{array}{lcc} & \text { Observed } \mathrm{M}_{\mathrm{r}} & \text { Calculated } \mathrm{M}_{\mathrm{r}} \\ \text { Insulin (gene 1) } & 5800.2 & 5800.7 \\ \text { Insulin (gene 2) } & 5813.6 & 5813.7 \\ \text { Insulin (gene 3) } & 5827.5 & 5827.7 \\ \text { Glucagon-36 (gene 1) } & 4240.3 & 4240.6 \\ \text { Glucagon-36 (gene 2) } & 4168.3 & 4168.5 \\ \text { GLP-1A (gene 1) } & 4076.2 & 4076.5 \\ \text { GLP-1A (gene 2) } & 4099.8 & 4099.5 \\ \text { GLP-1B (gene 1) } & 4387.6 & 4387.0 \\ \text { GLP-1C (gene 1) } & 3681.9 & 3682.2 \\ \text { GLP-1C (gene 2) } & 3667.8 & 3668.1 \\ \text { PP (gene 1) } & 4342.3 & 4342.6 \\ \text { PP (gene 2) } & 4356.2 & 4356.6\end{array}$

\section{Cynops pyrrhogaster}

$\begin{array}{lll}\text { Insulin } & 5826.1 & 5826.4 \\ \text { Glucagon-36 } & 4154.3 & 4154.6 \\ \text { GLP-1 } & 3320.4 & 3320.7 \\ \text { GLP-2 } & 3663.7 & 3664.1 \\ \text { PP } & 4214.2 & 4214.6\end{array}$

Figure 2 Molecular masses of the purified islet hormones from X. laevis and C. pyrrhogaster determined by electrospray mass spectrometry.

between $0 \cdot 0$ and $0 \cdot 25$ were pooled and pumped at a flow rate of $2 \mathrm{ml} / \mathrm{min}$ onto a $25 \times 1 \mathrm{~cm}$ Vydac $218 \mathrm{TP} 510$ C-18 reverse-phase HPLC column (Separations Group, Hesperia, CA, USA) equilibrated with $0 \cdot 1 \%(\mathrm{v} / \mathrm{v})$ trifluoroacetic acid/water. The concentration of acetonitrile in the eluting solvent was increased to $21 \%$ over $10 \mathrm{~min}$, followed by an increase to $49 \%$ over 60 min using linear gradients. Absorbance was measured at 214 and $280 \mathrm{~nm}$ and fractions $(1 \mathrm{~min})$ were collected. Aliquots of each fraction $(20 \mu \mathrm{l})$ were subjected to electrospray mass spectrometry to determine the molecular masses of the major components in that fraction. Individual fractions of interest were separately rechromatographed on a $25 \times 0.46 \mathrm{~cm}$ Vydac 214TP54 C-4 column equilibrated with acetonitrile/water/trifluoroacetic acid (21.0/78.9/ $0 \cdot 1)$ at a flow rate of $1.5 \mathrm{ml} / \mathrm{min}$. The concentration of acetonitrile in the eluting solvent was raised to $49 \%$ over 50 min using a linear gradient. Xenopus insulins and proglucagon-derived peptides were purified to apparent homogeneity by chromatography on a $25 \times 0.46 \mathrm{~cm}$ Vydac 219TP54 phenyl column using the same elution conditions as those for the C-4 column. The purification of two molecular forms of Xenopus PP has been described previously (Kim et al. 2001).

\section{Purification of the Cynops peptides}

The pancreatic extract, after partial purification on SepPak cartridges, was redissolved in $0 \cdot 1 \%$ trifluoroacetic $\mathrm{acid} /$ water $(5 \mathrm{ml})$ and injected onto a $25 \times 1 \mathrm{~cm}$ Vydac 218TP510 (C-18) HPLC column equilibrated with $0 \cdot 1 \%$ $(\mathrm{v} / \mathrm{v})$ trifluoroacetic acid/water at a flow rate of $2 \mathrm{ml} / \mathrm{min}$. The concentration of acetonitrile in the eluting solvent was increased to $21 \%$ over $10 \mathrm{~min}$, followed by an increase to $49 \%$ over 60 min using linear gradients. Absorbance was measured at 214 and $280 \mathrm{~nm}$ and fractions $(1 \mathrm{~min}$ ) were collected. Individual peptides were purified to near homogeneity by chromatography on Vydac C-4 and Vydac phenyl columns using the same elution conditions as for the Xenopus peptides.

\section{Structural characterization}

Xenopus insulin from gene 3 (approximately $1 \mathrm{nmol}$ ) and Cynops insulin (approximately $1 \mathrm{nmol}$ ) were separately reduced (dithiothreitol) and pyridylethylated (4vinylpyridine) as previously described (Conlon et al. 1995). The derivatized A-chains and $\mathrm{B}$-chains of the insulins were separated by reverse-phase HPLC on an analytical 

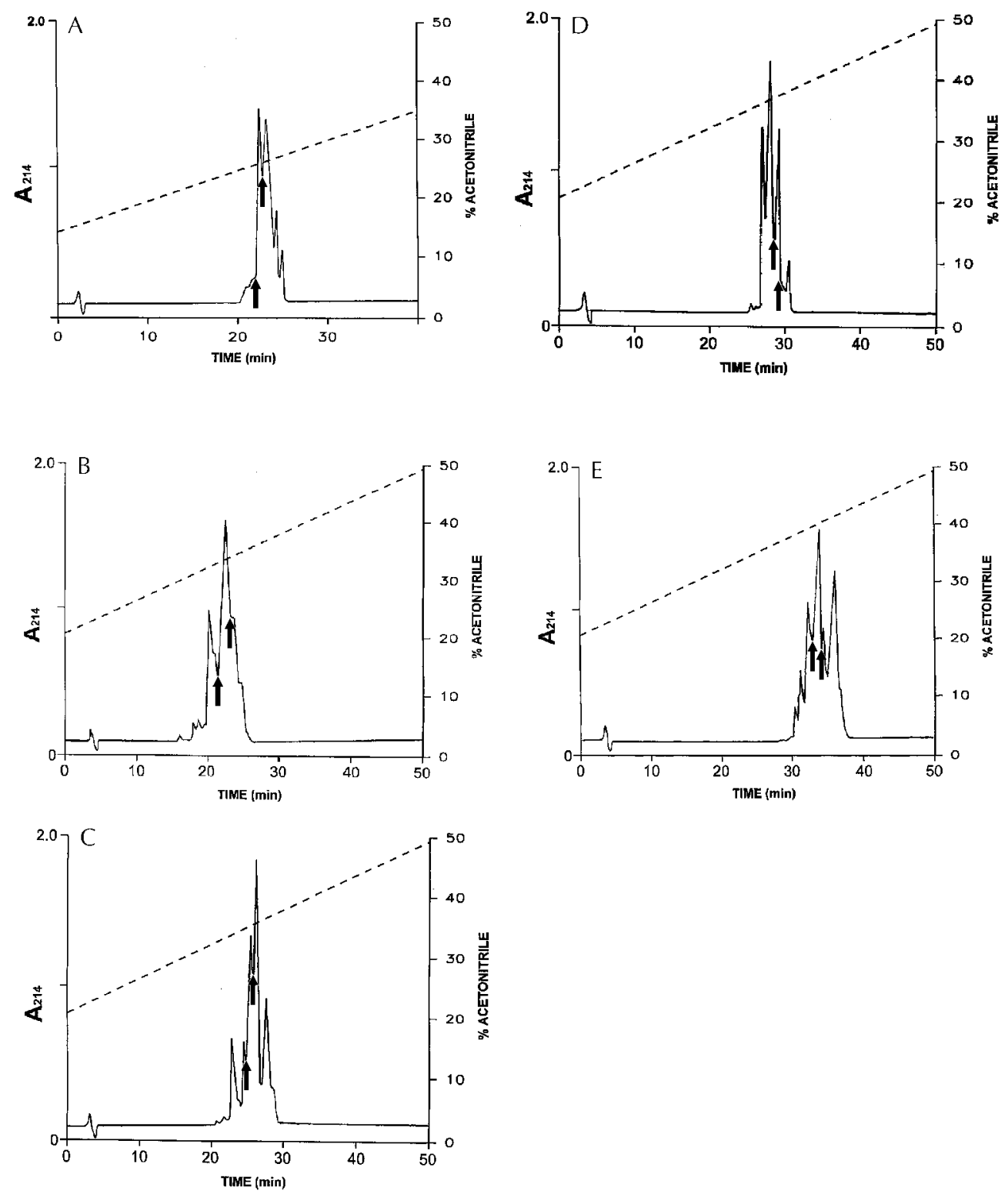

Figure 3 Reverse-phase HPLC on a Vydac C-4 column of Xenopus (A) glucagon-36 from genes 1 and 2 (fraction 1 in Fig. 1), (B) GLP-1B from gene 1(fraction 5), (C) GLP-1C from gene 1 (fraction 6), (D) GLP-1C from gene 2 (fraction 7) and (E) GLP-1A from genes 1 and 2 (fraction 8). The arrows show where peak collection began and ended. $\mathrm{A}_{214}$, absorbance at $214 \mathrm{~nm}$.

Vydac C-18 column under the conditions used for the purification of intact insulin.

The primary structures of the peptides were determined by automated Edman degradation using a Perkin Elmer model 491A sequenator (Perkin Elmer, Norwalk, CT, USA). Electrospray mass spectrometry was carried out using a Perkin Elmer Sciex API 150EX single quadrupole instrument. The accuracy of mass determinations was \pm $0 \cdot 05 \%$.

\section{Results}

Purification of the Xenopus peptides

The fractions from Sephadex G-25 chromatography that were eluted at, and immediately after, the void volume of the column $\left(K_{\mathrm{AV}}\right.$ between $0 \cdot 0$ and $\left.0 \cdot 25\right)$ were pooled and chromatographed on a semi-preparative Vydac C-18 reversed-phase HPLC column and the elution profile is shown in Fig. 1. The fractions were analyzed by 


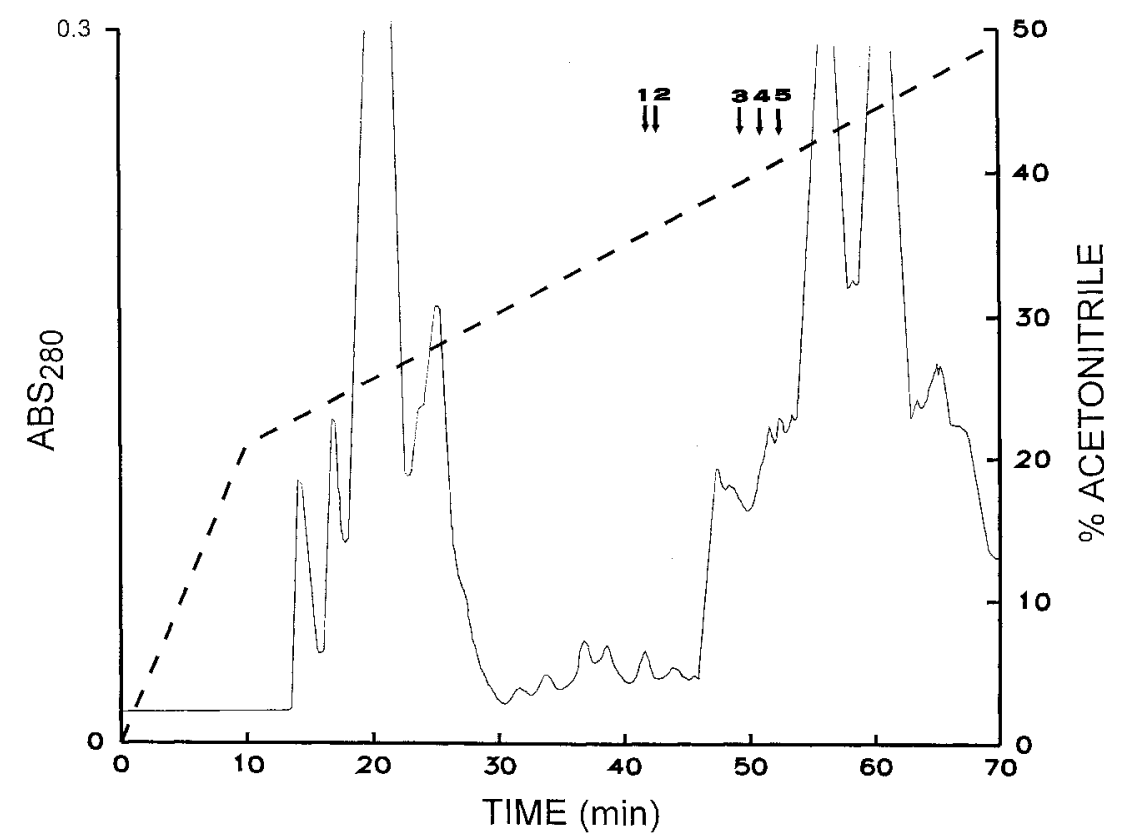

Figure 4 Reverse-phase HPLC on a Vydac C-18 column of an extract of the pancreas of Cynops pyrrhogaster after partial purification on Sep-Pak cartridges. The retention times of the islet hormones are denoted by: (1) insulin, (2) glucagon-36, (3) PP, (4) GLP-1 and

(5) GLP-2. The broken line shows the concentration of acetonitrile in the eluting solvent.

electrospray mass spectrometry with a view to identifying those fractions that contain peptides in major abundance in the molecular mass range 3000-6000 Da. Nine fractions with the retention times shown in Fig. 1 were selected for further purification and the masses of the peptides present in these fractions are shown in Fig. 2.

As the same techniques were used to isolate all peptides, only the chromatograms illustrating the purification of the Xenopus proglucagon-derived peptides are provided (Fig. 3). The elution profiles on an analytical Vydac C-4 column of glucagon-36 (Fig. 3A), GLP-1B from gene 1 (Fig. 3B), GLP-1C from gene 1 (Fig. 3C), GLP-1C from gene 2 (Fig. 3D) and GLP-1A (Fig. 3E) are shown. It was not possible to resolve glucagon-36 from genes 1 and 2 or GLP-1A from genes 1 and 2 on the Vydac C- 4 column but separation was accomplished on an analytical Vydac phenyl column.

\section{Purification of the Cynops peptides}

The elution profile on a semi-preparative Vydac C-18 column of the extract of Cynops pancreas, after partial purification on Sep-Pak cartridges, is shown in Fig. 4. Analysis of the fractions by electrospray mass spectrometry identified five fractions containing abundant peptides in the mass range 3000-6000 Da range. The observed masses of these components, subsequently shown to represent insulin (fraction 1), glucagon-36 (fraction 2), PP (fraction 3), GLP-1 (fraction 4) and GLP-2 (fraction 5), are shown in Fig. 2. The peptides were purified to near homogeneity, as assessed by a symmetrical peak shape and by mass spectrometry, on analytical Vydac C-4 and phenyl columns.

\section{Structural characterization}

The primary structures of the islet hormones from Xenopus and Cynops were determined without ambiguity by automated Edman degradation and their amino acid sequences are shown in Fig. 5. In all cases, the proposed structures were confirmed by mass spectrometry (Fig. 2). In both species, glucagon was isolated as a C-terminally extended component with 36 amino acid residues. Analysis of the fractions from HPLC (Figs 1 and 4) by mass spectrometry for the presence of Xenopus glucagon-29 (calculated $M_{\mathrm{r}}$ 3483) and Cynops glucagon-29 (calculated $M_{\mathrm{r}} 3483$ ) were unsuccessful, indicating that these components were not present in major abundance. Similarly, attempts to identify a component with the expected mass of Xenopus GLP-2 from preproglucagon gene 1 or a second peptide paralagous to Xenopus GLP-1B arising from gene 2 were unsuccessful.

\section{Discussion}

Previous studies designed to characterize islet hormones in non-mammalian vertebrates have focused upon the higher 


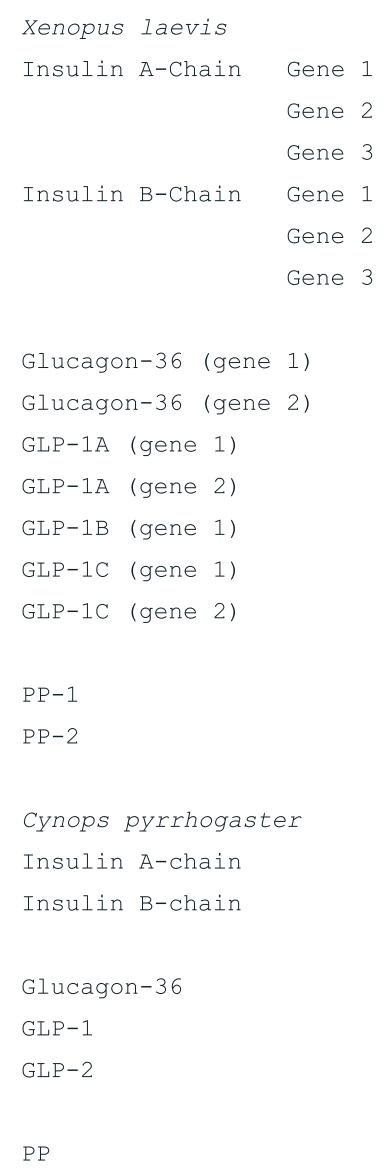

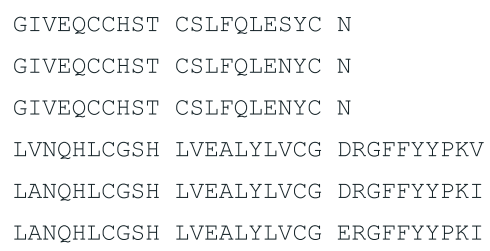

Figure 5 Primary structures of the islet hormones isolated from the pancreata of Xenopus laevis and Cynops pyrrhogaster. The residues in square brackets show the amino acids flanking the hormonal sequences in the preproglucagon precursors, as deduced from the nucleotide sequences of cDNAs.

teleost fishes as the complete or partial separation of endocrine and exocrine tissue in the Brockmann bodies (principal islets) of certain species has greatly facilitated the purification of the peptides. Mass spectrometry (the more cumbersome technique of fast-atom bombardment mass spectrometry in earlier studies) has been used primarily to confirm the identity of the purified islet hormones from extracts of the Brockmann bodies of the anglerfish Lophius americanus (Andrews et al. 1986, 1987, Nichols et al. 1988), catfish Ictalurus punctatus (Andrews \& Ronner 1985, Mommsen et al. 2002), daddy sculpin Cottus scorpius (Conlon et al. 1987a,b), tilapia Oreochromis nilotica (Nguyen et al. 1995) and pacu Piaractus mesopotamicus (Ferraz de Lima et al. 1999). The present study has used electrospray mass spectrometry to identify insulins, proglucagonderived peptides and PP in chromatographic fractions from extracts of the disseminated pancreatic glands of the amphibians $X$. laevis and $C$. pyrrhogaster without the need for additional techniques of detection such as radioimmunoassay, radioreceptor assay or bioassay.

Consistent with the fact that $X$. laevis is a tetraploid organism (Kobel \& Du Pasquier 1991), cDNAs encoding two non-allelic preproinsulins have been identified in a pancreatic cDNA library (Shuldiner et al. 1989). Mass spectrometry has identified both gene 1 and gene 2 insulins, whose primary structures are shown in Fig. 5, in the pancreatic extract but a third insulin was also purified and characterized that differs from insulin- 2 by the single amino acid substitution Asp ${ }^{21} \rightarrow$ Glu in the B-chain. The identification of this additional component may be a consequence of a localized gene duplication within the Xenopus lineage occurring after the putative tetraploidization event or may reflect heterozygosity. Studies in the carp Cyprinus carpio suggest that allelic variability tends to increase after tetraploidization (Larhammar \& Risinger 1994). 
A-Chain

\begin{abstract}
Human
Cynops

Amphiuma

Siren

Human

Cynops

Amphiuma

Siren
\end{abstract}

Human

Cynops

Amphiuma

Human

Cynops

Amphiuma

Human

Cynops

Amphiuma

Human

Cynops

Amphiuma

Siren

Figure 6 A comparison of the primary structures of the known islet hormones from three species of Caudata: the red-bellied newt Cynops pyrrhogaster, the three-toed amphiuma Amphiuma tridactylum and the lesser siren Siren intermedia, with their orthologs from the human. - denotes residue identity.

Nucleotide sequence analysis of a cloned cDNA encoding preproglucagon-1 from $X$. laevis has shown that, after removal of the signal peptide, the precursor comprises 246 amino acids and contains the sequences of three peptides with structural similarity to GLP-1 (termed GLP-1A, GLP-1B, and GLP-1C) arranged in tandem, as well as sequences corresponding to mammalian glucagon and GLP-2 (Irwin et al. 1997). In addition, the nucleotide sequence of a second Xenopus preproglucagon cDNA, encoding an identical glucagon but lacking the GLP-2 domain, has been deposited in the Gene Bank database (accession number AF004433 1) by the same investigators. The pathway of post-translational processing of the Xenopus preproglucagons is not known, so it is unclear which, if any, of the GLP-1 peptides are produced in vivo. The present study has shown that preproglucagons from gene 1 and 2 are not processed to glucagon-29, the primary gene product in the pancreata of mammals, but to a C-terminally extended component that corresponds to mammalian glucagon-37 (oxyntomodulin) (Tager \& Steiner 1973). The concentrations of C-terminally extended forms of glucagon are higher than the concentrations of glucagon-29 in the pancreata of several species of anurans that have been examined (Rana catesbeiana (Pollock et al. 1988), Bufo marinus (Conlon et al. 1998a), Ceratophrys ornata (White et al. 1999) and Pipa pipa (Matutte \& Conlon 2000)). As shown in Fig. 5, processing of preproglucagon to generate glucagon-36 (gene 1 and 2), GLP-1A (gene 1 and 2) and GLP-1C (gene 2) involves proteolytic cleavage at the site of dibasic residues (Arg-Arg and Arg-Lys) whereas generation of GLP-1B (gene 1) and GLP-1C (gene 1) involves cleavage of a monobasic (single Arg) site.

The newt C. pyrrhogaster is classified taxonomically in the family Salamandridae which is grouped with the Amphiumidae (amphiumas), Plethodontidae (lungless salamanders), Ambystomatidae (axolotls), Proteidae (mudpuppies), Rhyacotritonidae (torrent salamanders) and Dicamtodontidae (Pacific giant salamanders) in the suborder Salamandroidea. The Salamandroidea are sistergroup to the Cryptobranchoidea (hellbenders) with the Sirenidae (sirens) as outgroup (Titus \& Larson 1995). Consistent with this phylogenetic scheme, the primary structure of Cynops insulin shows greater structural similarity to insulin from the three-toed amphiuma Amphiuma tridactylum (Conlon et al. 1996) (eight substitutions) than to insulin from the lesser siren Siren intermedia (Conlon et al. 1997) (fourteen substitutions) (Fig. 6). However, Cynops insulin lacks the dipeptide extension to the $\mathrm{N}$ terminus of the A-chain that is found in amphiuma insulin, indicating that the pathway of post-translational processing of Cynops proinsulin is not anomalous. Those residues in human insulin that are believed to be important in maintaining the receptor-binding conformation (Kristensen et al. 1997, Conlon 2001) have been conserved in Cynops insulin.

The amino acid sequences of Cynops GLP-1 and GLP-2 also resemble closely the corresponding peptides from the amphiuma (Cavanaugh et al. 1996). In amphiuma proglucagon, the Arg-Arg dibasic residue sequence located at the C terminus of GLP-1 $\left(\mathrm{Gly}^{31}-\mathrm{Arg}^{32}-\mathrm{Arg}^{33}-\mathrm{Gln}^{34}\right)$ is not recognized by a processing enzyme, whereas in Cynops proglucagon this dibasic pair is proteolytically cleaved and the $\mathrm{Gly}^{31}$ residue acts as a substrate for peptidylglycine $\alpha$-amidating mono-oxygenase to produce a C-terminally $\alpha$-amidated GLP-1. Cleavage at dibasic residue sites by the prohormone convertases PC1 (SPC3) and PC2 is promoted when the site is situated adjacent to a $\beta$-turn or $\Omega$-loop and inhibited when the site forms part of an $\alpha$-helix (Steiner 1998). Substitution of the $\operatorname{Ser}^{28}$ residue in amphiuma GLP-1 by Asn, a residue that destabilizes $\alpha$-helices in proteins, in Cynops GLP-1 may be responsible for the different pathways of processing of the two preproglucagons.

The primary structure of PP has been poorly conserved among non-mammalian tetrapods and it has been proposed that the amino acid sequence of the peptide may be a useful molecular marker for inferring phylogenetic 
relationships between species (Conlon et al. 1998b). In this light, the primary structure of Cynops $\mathrm{PP}$ appears to be anomalous. As shown in Fig. 6, Cynops PP differs from amphiuma PP by eight amino acids but from siren PP by only three amino acids. This is inconsistent with the proposed closer phylogenetic relationship between the newts and the amphiuma based upon morphological criteria and mitochondrial DNA sequences (Titus \& Larson 1995). The physiological role of PP, if any, in amphibians is unknown.

\section{Acknowlegements}

The authors thank Dr Yousef Basir and Ms Eva Lovas, Creighton University Medical School, for mass spectrometry measurements. This work was supported by a grant from the National Science Foundation (EPS9720643).

\section{References}

Andrews PC \& Ronner P 1985 Isolation and structures of glucagon and glucagon-like peptide from catfish pancreas. Journal of Biological Chemistry 260 3910-3914.

Andrews PC, Hawke DH, Lee TD, Legesse K, Noe BD \& Shively JE 1986 Isolation and structure of the principal products of preproglucagon processing, including an amidated glucagon-like peptide. Journal of Biological Chemistry 261 8128-8133.

Andrews PC, Nichols R \& Dixon JE 1987 Post-translational processing of preprosomatostatin-II examined using fast atom bombardment mass spectrometry. Journal of Biological Chemistry 262 12692-12699.

Cavanaugh ES, Nielsen PF \& Conlon JM 1996 Isolation and structural characterization of proglucagon-derived peptides, pancreatic polypeptide and somatostatin from the urodele, Amphiuma tridactylum. General and Comparative Endocrinology 101 12-20.

Conlon JM 2001 Evolution of the insulin molecule: insights into structure-activity and phylogenetic relationships. Peptides $\mathbf{2 2}$ 1183-1193.

Conlon JM, Davis MS, Falkmer S \& Thim L 1987a Structural characterization of peptides derived from prosomatostatin I and II isolated from the pancreatic islets of two species of teleostean fish: the daddy sculpin and the flounder. European Journal of Biochemistry 168 647-652.

Conlon JM, Falkmer S \& Thim L 1987b Primary structures of three fragments of proglucagon from the pancreatic islets of the daddy sculpin (Cottus scorpius). European Journal of Biochemistry 164 117-122.

Conlon JM, Hilscher-Conklin C \& Boyd SK 1995 Purification and structural characterization of insulin from a caecilian, Typhlonectes natans (Amphibia: Gymnophiona). Peptides 16 1385-1388.

Conlon JM, Cavanaugh ES, Mynarcik DC \& Whittaker J 1996 Characterization of an insulin from the amphiuma (Amphibia: Urodela) with an $\mathrm{N}$-terminally extended A-chain and high receptor-binding affinity. Biochemical Journal 313 283-287.

Conlon JM, Trauth SE \& Sever DM 1997 Purification and structural characterization of insulin from the lesser siren, Siren intermedia (Amphibia: Caudata). General and Comparative Endocrinology 106 295-300.

Conlon JM, Abdel-Wahab YHA, O'Harte FPM, Nielsen PF \& Whittaker J 1998a Purification and characterization of insulin, glucagon and two glucagon-like peptides with insulin-releasing activity from the pancreas of the toad, Bufo marinus. Endocrinology $1393442-3448$.

Conlon JM, Platz JE, Chartrel N, Vaudry H \& Nielsen PF 1998 b Amino acid sequence diversity of pancreatic polypeptide among amphibia. General and Comparative Endocrinology 112 146-152.

Dongre AR, Opiteck G, Cosand WL \& Hefta SA 2001 Proteomics in the post-genome age. Biopolymers 60 206-211.

Ferraz de Lima JA, Oliveira B \& Conlon JM 1999 Purification and characterization of insulin and peptides derived from proglucagon and prosomatostatin from the fruit-eating fish, the pacu Piaractus mesopotamicus. Comparative Biochemistry and Physiology 122B 127-135.

Irwin DM, Satkunarajah M, Wen Y, Brubaker PL, Pederson RA \& Wheeler MB 1997 The Xenopus proglucagon gene encodes novel GLP-1-like peptides with insulinotropic properties. PNAS 94 7915-7920.

Jacob HJ \& Kwitek AE 2002 Rat genetics: attaching physiology and pharmacology to the genome. Nature Reviews. Genetics 3 33-42.

Kim JB, Johansson Å \& Conlon JM 2001 Anomalous rates of evolution of pancreatic polypeptide and peptide tyrosine-tyrosine (PYY) in a tetraploid frog, Xenopus laevis (Anura: Pipidae). Peptides 22 317-323.

Klose J, Nock C, Herrman M, Stuhler K, Marcus K, Bluggel M, Krause E, Schalkwyk LC, Rastan S, Brown SD, Bussow K, Himmelbauer H \& Lehrach H 2002 Genetic analysis of the mouse brain proteome. Nature Genetics 30 385-393.

Kobel HR \& Du Pasquier L 1991 Genetics of Xenopus laevis. Methods in Cell Biology 36 19-34.

Kristensen C, Kjeldsen T, Wiberg FC, Schaffer L, Hach M, Havelund S, Bass J, Steiner DF \& Andersen AS 1997 Alanine scanning mutagenesis of insulin. Journal of Biological Chemistry 272 12978-12983.

Larhammar D \& Risinger C 1994 Molecular genetic aspects of tetraploidy in the common carp Cyprinus carpio. Molecular Phylogenetics and Evolution 3 59-68.

Liu H, Lin D \& Yates JR 2002 Multidimensional separations for protein/peptide analysis in the post-genomic era. Biotechniques 32 898-902.

Matutte B \& Conlon JM 2000 Characterization of insulin and atypically processed proglucagon-derived peptides from the Surinam toad Pipa pipa (Anura: Pipidae). Peptides 21 1357-1362.

Mommsen TP, Silverstein JT, Plisetskaya EM, Whittaker LJ, Whittaker J \& Conlon JM 2002 Two insulins from channel catfish: purification, structures, receptor-binding and cDNA sequences. Fish Physiology and Biochemistry 25 61-71.

Nguyen TM, Wright JR, Nielsen PF \& Conlon JM 1995 Characterization of the pancreatic hormones from the Brockmann body of the tilapia - implications for islet xenograft studies. Comparative Biochemistry and Physiology 111 33-44.

Nichols R, Lee TD \& Andrews PC 1988 Pancreatic proglucagon processing: isolation and structures of glucagon and glucagon-like peptide from gene I. Endocrinology 123 2639-2645.

Patton EE \& Zon LI 2001 The art and design of genetic screens: zebrafish. Nature Reviews. Genetics 2 956-966.

Pollock HG, Hamilton JW, Rouse JB, Ebner KE \& Rawitch AB 1988 Isolation of peptide hormones from the pancreas of the bullfrog (Rana catesbeiana). Journal of Biological Chemistry 263 9746-9751.

Rabilloud T 2002 Two-dimensional gel electrophoresis in proteomics: old, old-fashioned, but it still climbs up the mountains. Proteomics 2 $3-10$.

Saccone C, Gissi C, Reyes A, Larizza A, Sbisa E \& Pesole G 2002 Mitochondrial DNA in metazoa: degree of freedom in a frozen event. Gene 286 3-12.

Shuldiner AR, Phillips S, Roberts CT Jr, LeRoith D \& Roth J 1989 Xenopus laevis contains two nonallelic preproinsulin genes. cDNA cloning and evolutionary perspective. Journal of Biological Chemistry $2649428-9432$. 
Steiner DF 1998 The proprotein convertases. Current Opinions in Chemistry and Biology 2 31-39.

Tager HS \& Steiner DF 1973 Isolation of a glucagon-containing peptide: primary structure of a possible fragment of proglucagon. PNAS 70 2321-2325.

Titus TA \& Larson A 1995 A molecular phylogenetic perspective on the evolutionary radiation of the salamander family Salamandridae. Systematic Biology 44 125-151.

Venkatesch B, Gilligan P \& Brenner S 2000 Fugu: a compact vertebrate reference genome. FEBS Letters 476 3-7.
White AM, Secor SM \& Conlon JM 1999 Insulin and proglucagonderived peptides from the horned frog, Ceratophrys ornata (Anura: Leptodactylidae). General and Comparative Endocrinology 115 143-154.

Wittbrodt J, Shima A \& Schartl M 2002 Medaka - a model organism from the Far East. Nature Reviews. Genetics 3 53-64.

Received in final form 19 August 2002

Accepted 22 August 2002 